\title{
Regulation of Extracellular Matrix by Mechanical Stress in Rat Glomerular Mesangial Cells
}

\author{
Takashi Yasuda, Satoshi Kondo, Toshio Homma, and Raymond C. Harris \\ Division of Nephrology, Department of Medicine, Vanderbilt University School of Medicine, and Department of Veterans Affairs Medical \\ Center, Nashville, Tennessee 37232
}

\begin{abstract}
Increases in intraglomerular pressure are known to predispose to the development of glomerular sclerosis, which is characterized by accumulation of extracellular matrix within the glomerulus. Glomerular mesangial cells are exposed to pulsatile capillary pressures and are a potential target for mechanical stress. In the present studies, we subjected cultured rat mesangial cells to continuous cycles of stretching and relaxation (stretch/relaxation) and examined alterations in extracellular matrix gene expression.

After $48 \mathrm{~h}$ of stretch/relaxation, immunofluorescent localization of matrix accumulation indicated increases in types I, III, and IV collagens, fibronectin, and laminin, with the greatest increases seen at the periphery of the culture dish, at the point of the greatest deformation. Northern blot analysis of total RNA revealed time-dependent induction of $\alpha 1(\mathrm{I})$ collagen, $\alpha 1$ (III) collagen, $\alpha 1$ (IV) collagen, fibronectin, and laminin by stretch/relaxation, with maximal increases occurring between 12 and $24 \mathrm{~h}$. Transient transfection of reporter gene constructs of the $5^{\prime}$ flanking region of $\alpha 1(\mathrm{I})$ collagen gene indicated that stimulation of gene transcription was involved in the increased expression of matrix mRNA. Gelatinolytic activity in conditioned media was decreased at 24 and $48 \mathrm{~h}$ of stretch/relaxation, in association with a significant decrease in levels of mRNA for matrix metalloproteinase-2 (68-72 $\mathrm{kD}$ type IV collagenase) occurring within $6 \mathrm{~h}$ of stretch/relaxation. In contrast, expression of tissue inhibitor of metalloproteinase- 2 was increased within $12 \mathrm{~h}$ of stretch/relaxation. Stretch/relaxation increased immunoreactive TGF- $\beta$ at 48 but not $12 \mathrm{~h}$. TGF- $\beta 1 \mathrm{mRNA}$ levels remained unchanged during the initial $12 \mathrm{~h}$ of stretch/ relaxation, but were significantly elevated at $48 \mathrm{~h}$, and no differences in TGF- $\beta$ bioactivity could be detected in conditioned media for up to $12 \mathrm{~h}$ of stretch/relaxation. These findings demonstrate that in glomerular mesangial cells, repeated cycles of stretching and relaxation lead to matrix accumulation by stimulating production of extracellular matrix and decreasing activity of degradative enzymes. The observed induction of TGF- $\beta 1$ suggests a role in matrix accumulation occurring in response to continued mechanical deformation. (J. Clin. Invest. 1996. 98:1991-2000.) Key
\end{abstract}

Address correspondence to Raymond C. Harris, Division of Nephrology, Department of Medicine, S-3223 Medical Center North, Nashville, TN 37232. Phone: 615-343-0030; FAX: 615-343-7156.

Received for publication 4 December 1995 and accepted in revised form 21 August 1996.

The Journal of Clinical Investigation

Volume 98, Number 9, November 1996, 1991-2000 words: glomerulus - extracellular matrix - transforming growth factor $-\beta \cdot$ collagen $\cdot$ metalloproteinase

\section{Introduction}

Expansion of the mesangium, due to proliferation or hypertrophy of mesangial cells and an increase in extracellular matrix, is a common finding in most progressive renal diseases. Expanded mesangium and sclerotic glomeruli contain normal mesangial matrix components, including type IV collagen, laminin, and heparan sulfate proteoglycan, as well as types I and III collagens, which are not normally present in glomerular matrix (1-3). Accumulation of extracellular matrix components occurs as the result of an increase in production of normal and/or abnormal matrix components or a decrease in matrix degradation. Matrix-degrading metalloproteinases are regulated at the level of synthesis and precursor activation, and by the inhibitors of metalloproteinases, tissue inhibitor of metalloproteinases (TIMP) $)^{1}(4,5)$.

In the kidney, glomerular hypertrophy and the ultimate development of sclerosis and glomerular obsolescence are associated with pathophysiologic conditions such as diabetes mellitus or loss of functioning renal mass (6). In noninflammatory states, increased glomerular and tubulointerstitial matrix production occur in association with elevations in glomerular capillary pressure and glomerular filtration rate. It has not been elucidated whether glomerulosclerosis occurs as a direct result of the increased intraglomerular pressure or as a secondary response to increased intraglomerular angiotensin II, and/or cytokines or growth factors such as IL-1, TGF- $\beta$, PDGF, and EGF $(7,8)$. Accumulating evidence indicates a preeminent role for TGF- $\beta$ in the accumulation of extracellular mesangial matrix $(7,9,10)$, and an important role of TGF- $\beta$ in the accumulation of extracellular matrix in glomerulonephritis was demonstrated by Okuda et al. and Border et al. (10-12). Recently, Isaka et al. (13) have shown that in vivo transfection of TGF- $\beta 1$ in the kidney resulted in an expansion of mesangial matrix. TGF- $\beta$ has effects not only on the rate of extracellular matrix synthesis, but also on the expression of metalloproteinase, TIMPs, and extracellular matrix receptors on cells (14).

Since increases in glomerular filtration rate and glomerular capillary pressure are associated with conditions that predispose to the development of these glomerular abnormalities, it has also been hypothesized that the increased mechanical tension generated by elevated glomerular filtration rate and glomerular capillary pressure might itself be a primary cause of the glomerular deterioration. Studies by Brenner (15) have suggested that the increased mechanical tension generated by elevated glomerular filtration rates and glomerular capillary

1. Abbreviations used in this paper: GAPDH, glyceraldehyde-3-phosphate dehydrogenase; TIMP, tissue inhibitor of metalloproteinases. 

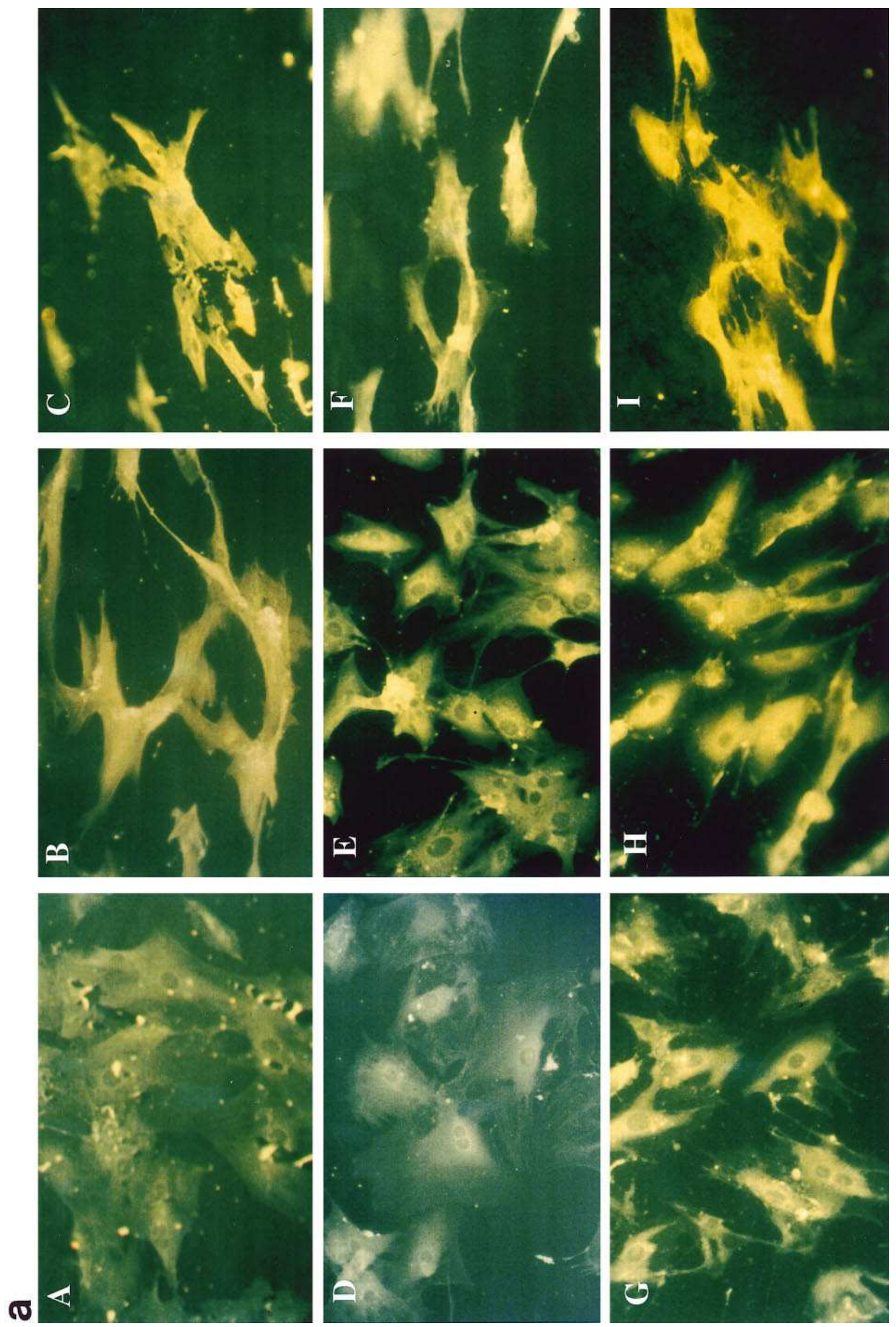

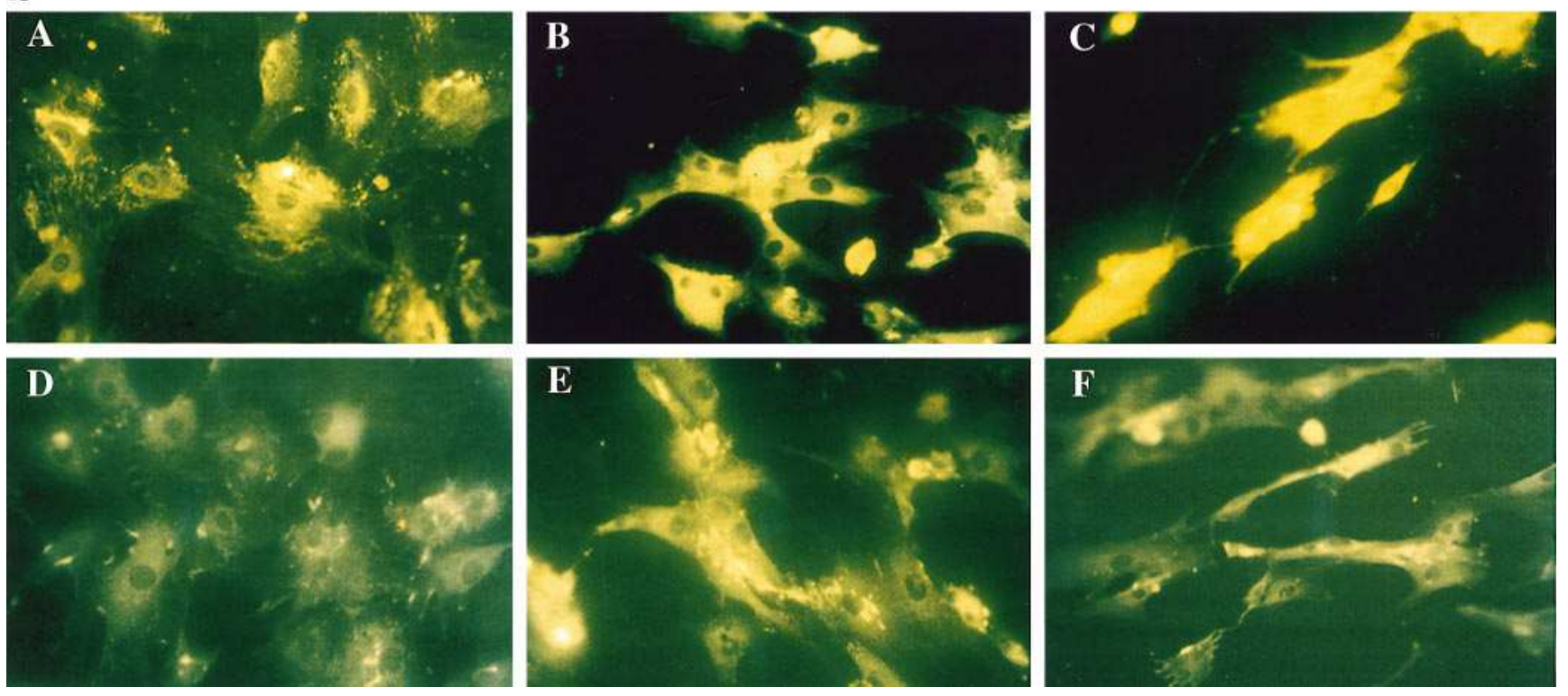

Figure 1. (a) Immunofluorescence of type I $(A, B$, and $C)$, type III $(D, E$, and $F)$, and type IV $(G, H$, and $I)$ collagens. $(A, D$, and $G)$ Cells without stretch/relaxation; $(B, E$, and $H)$ cells in midperipheral portion of the well after $48 \mathrm{~h}$ stretch/relaxation; $(C, F$, and $I)$ cells in peripheral portion of the well after $48 \mathrm{~h}$ stretch/relaxation. (b) Immunofluorescence of fibronectin $(A, B$, and $C)$ and laminin $(D, E$, and $F)$. ( $A$ and $D)$ Cells without stretch/relaxation; $(B$ and $E$ ) cells in midperipheral portion of the well after $48 \mathrm{~h}$ stretch/relaxation; $(C$ and $F)$ cells in peripheral portion of the well after $48 \mathrm{~h}$ stretch/relaxation.

pressure is a primary cause of the glomerular deterioration. Mesangial cells and glomerular basement membrane have extensive interconnections, and mesangial cells are exposed to the high pulsatile glomerular capillary pressures necessary to sustain normal glomerular filtration rate (16). Thus, mesangial cells may be a primary target within the glomerulus for the increased mechanical stress that may initiate the development of glomerular abnormalities.

There has been increasing interest in the role of physical factors in the regulation of structure and function of cardiac and smooth muscle cells $(17,18)$ and mesangial cells (19-22). In previous studies, we and others have demonstrated that continuous cycles of stretch and relaxation (stretch/relaxation) induce increased production of proteins, especially extracellular matrix proteins (19-22). However, the mechanisms involved in the induction of increased matrix synthesis by mesangial cells are incompletely understood. The present studies were designed to examine the effect of mechanical stretch/relaxation upon alterations in extracellular matrix synthesis by cultured rat mesangial cells and to determine whether alterations in TGF- $\beta$ expression precede any alterations in production of matrix components.

\section{Methods}

Materials. $\left[\alpha^{-32} \mathrm{P}\right] \mathrm{CTP}(3,000 \mathrm{Ci} / \mathrm{mmol})$ was from DuPont-NEN (Boston, MA). The cDNA probes used for Northern blot analysis were as follows: $1.3 \mathrm{~kb}$ Pst1-BamH1 fragment of p $\alpha 1 \mathrm{R} 1$ for rat $\alpha 1$ (I) collagen (23), $2.2 \mathrm{~kb}$ PvuII fragment of pRGR5 for rat pro- $\alpha 1$ (III) collagen (24), $0.62 \mathrm{~kb}$ PstI-PvuII fragment of pCV-1-C87 for mouse $\alpha 1$ (IV) collagen (25), $0.27 \mathrm{~kb}$ HindIII-EcoRI fragment of p-SR270 for rat fibronectin (26), $1.3 \mathrm{~kb}$ EcoRI fragment of HL-40 for human laminin, B1 polypeptide (27), $2.1 \mathrm{~kb}$ EcoRI fragment of human ma- trix metalloproteinase 2 (MMP-2) (28), $0.6 \mathrm{~kb}$ EcoRI fragment of human tissue inhibitor of metalloproteinase 2 (TIMP-2), $3.9 \mathrm{~kb}$ the XbaI fragment of pTZ for human TIMP-1 (29), and $2.0 \mathrm{~kb}$ EcoRI fragment of hTGF $\beta-2$ for human TGF- $\beta 1$ (30). The plasmids that contain the untranslated $5^{\prime}$ regions of the mouse $\alpha 1(\mathrm{I})$ collagen gene linked to chloramphenicol acetyltransferase gene, pG 70, pG 100, and pG 60 were the generous gift of Dr. B. de Crombrugghe (31). The untranslated $5^{\prime}$ regions of the mouse $\alpha 1(\mathrm{I})$ collagen gene were excised from the plasmid pG $70(-2.4 \mathrm{~K}$ to +116 base), pG 100 ( -900 to +116 base) and pG 60 ( -222 to +116 base), and linked upstream to a luciferase reporter gene in pGL2 basic (Promega Corp., Madison, WI), producing pGL 2.4, pGL 0.9 , and pGL 0.22 , respectively. Primary antibodies used in these experiments were rabbit anti-rat type I collagen, rabbit anti-rat type III collagen, rabbit anti-collagen type IV extracted from murine EHS tumor (Pasteur Inst., Lyon, France), rabbit anti-rat fibronectin (Calbiochem Corp., La Jolla, CA), rabbit anti-laminin extracted from murine EHS tumor (Sigma Chemical Co., St. Louis, MO) and anti-TGF- $\beta 1$ antibody (R\&D Systems, Inc., Minneapolis, MN). Biotinylated goat anti-rabbit IgG and avidin-fluorescin were from Pierce Chemical Co. (Rockford, IL).

Cell culture. Rat glomerular mesangial cells were cultured and maintained in RPMI 1640 supplemented with $10 \%$ fetal bovine serum, penicillin $(100 \mathrm{U} / \mathrm{ml})$, and streptomycin $(100 \mathrm{mg} / \mathrm{ml})$ at $37^{\circ} \mathrm{C}$ in $95 \%$ air $/ 5 \% \mathrm{CO}_{2}$ atmosphere, as described previously (32). All experiments were carried out on cells of passages 5-10.

Application of continuous cycles of stretch/relaxation. Stretch/relaxation of mesangial cells was accomplished as described previously (19-21). Briefly, mesangial cells were plated onto six-well plates with either a flexible or rigid bottom coated with bovine type I collagen (Flexcell Corp., McKeesport, PA). Cells were grown to confluence and rendered quiescent by incubation for $2 \mathrm{~d}$ in RPMI supplemented with $0.4 \%$ fetal bovine serum. Cells grown on the flexible surface were exposed to cycles of stretching and relaxation using a computerdriven, vacuum-operated, stress-providing instrument (Flexercell Strain Unit 100B; Flexcell Corp.). Cultures were exposed to continuous cycles of stretch/relaxation, with each cycle consisting of $2 \mathrm{~s}$ of 
stretching and $2 \mathrm{~s}$ of relaxation. The vacuum induced $9-12 \%$ elongation in the diameter of the surface. In selected plates, $30 \mu \mathrm{g} / \mathrm{ml}$ of a neutralizing polyclonal rabbit anti-TGF- $\beta 1$ antibody (R\&D Systems, Inc.) was added before institution of mechanical stretching.

RNA isolation and Northern analysis. Total RNA from the cells at various times after initiation of stretch/relaxation was isolated by the acid guanidium thiocyanate-phenol-chloroform method (33). Samples of RNA, each consisting of $7.5 \mu \mathrm{g}$, were subjected to electrophoresis in denaturing $1 \%$ agarose $/ 2.2 \mathrm{M}$ formaldehyde gels in 20 $\mathrm{mM}$ MOPS and transferred overnight by capillary blotting in $10 \times$ SSC (1.5 M NaCl, $0.15 \mathrm{M}$ sodium citrate, $\mathrm{pH} 7.0)$ to nylon membranes (S\&S Nytran plus; Schleicher \& Schuell, Inc., Keene, NH). RNA was fixed to the membrane by exposing to ultraviolet light (GS Gene Linker UV Chamber; Bio-Rad Laboratories, Hercules, CA.) Blots were prehybridized for $4 \mathrm{~h}$ at $42^{\circ} \mathrm{C}$ in $30 \%$ formamide for fibronectin, laminin, MMP-2, TIMP-2, and TGF- $\beta 1$ probe, or $50 \%$ formamide for $\alpha 1(\mathrm{I}), \alpha 1(\mathrm{III})$, and $\alpha(\mathrm{IV})$ collagen, $0.1 \%$ SDS, $50 \mathrm{mM} \mathrm{NaH}_{2} \mathrm{PO}_{4}(\mathrm{pH}$ $7.0), 5 \times$ Denhardt's solution $(0.1 \%$ bovine serum albumin, Ficoll, and polyvinylpyrrolidine), $100 \mu \mathrm{g} / \mathrm{ml}$ salmon sperm DNA, and $5 \times$ SSC. Blots were hybridized with $2-5 \times 10^{6} \mathrm{cpm} / \mathrm{ml}$ of ${ }^{32} \mathrm{P}$-labeled cDNA overnight at $42^{\circ} \mathrm{C}$ in a fresh hybridization buffer. Hybridization buffer was the same as the prehybridization buffer except for the addition of $10 \%$ dextran sulfate. The cDNA probes were labeled to at least $10^{8} \mathrm{cpm} / \mathrm{mg}$ by the random priming procedure using commercially available kits (Amersham Corp., Arlington Heights, IL). The membranes were washed in $2 \times \mathrm{SSC}, 0.1 \% \mathrm{SDS}$ for $20 \mathrm{~min}$ at room temperature, followed by two washes in $0.2 \times$ SSC, $0.1 \%$ SDS for 20 min at $65^{\circ} \mathrm{C}$, and exposed to X-Omat AR film (Eastman Kodak Co., Rochester, NY) at $-70^{\circ} \mathrm{C}$ with an intensifying screen. To normalize mRNA content, blots were stripped and reprobed with a human glyceraldehyde-3-phosphate dehydrogenase (GAPDH) cDNA (Clontech, Palo Alto, CA), using the conditions of labeling, hybridization, and wash as described above. The levels of transcript were quantitated by densitometry (Hoefer Scientific Instruments, San Francisco, CA) and normalized to the amount of GAPDH.

Immunostaining. Mesangial cells were plated at a density of $5 \times$ $10^{4} /$ well onto rigid or flexible bottom plates. $2 \mathrm{~d}$ after seeding, cells were rendered quiescent for $48 \mathrm{~h}$ in RPMI with $0.4 \% \mathrm{FBS}$, and then subjected to stretch/relaxation for $48 \mathrm{~h}$ in the same medium. Cells were washed twice with PBS and fixed with $95 \%$ ethanol for $30 \mathrm{~min}$ at $-20^{\circ} \mathrm{C}$, then blocked with rabbit serum in PBS, followed by two washes with PBS. Cells were then incubated with primary antibody against specific extracellular matrix component for $1 \mathrm{~h}$ at $37^{\circ} \mathrm{C}$. After three washes with PBS, cells were incubated with biotinylated antirabbit antibody for $1 \mathrm{~h}$ at $37^{\circ} \mathrm{C}$. Cells were then washed five times with PBS and incubated with $20 \mu \mathrm{g} / \mathrm{ml}$ avidin-fluorescin in $10 \mathrm{mM}$ Hepes, $0.15 \mathrm{M} \mathrm{NaCl}, \mathrm{pH} 7.5$, for $30 \mathrm{~min}$ at $37^{\circ} \mathrm{C}$, and washed twice with PBS, mounted and examined by fluorescent microscopy.

The concentration of antibodies used in these experiments were: 1:50 dilution of antibodies against types I, III, and IV collagens, 1:100 dilution of anti-TGF- $\beta, 1: 200$ dilution of antilaminin and 1:400 dilution of antifibronectin.

Gelatin-substrate enzymography. Changes in the release of gelatin-degrading proteinase by stretch/relaxation in mesangial cells were examined by gelatin-substrate enzymography according to the method of Heussen and Dowdle (34). Briefly, aliquots of conditioned medium (RPMI $+0.4 \%$ FCS) were harvested at various time intervals from either stretch/relaxation or control wells and centrifuged to remove debris. $20 \mu \mathrm{l}$ of conditioned medium were solubilized in nonreducing buffer and electrophoresed in 10\% SDS-polyacrylamide gel containing $0.1 \%$ gelatin. After electrophoresis, SDS was removed from the gel by $2.5 \%$ Triton X-100 washes. The gel was then washed in $50 \mathrm{mM}$ Tris- $\mathrm{HCl}, \mathrm{pH} 7.6$, containing $5 \mathrm{mM} \mathrm{CaCl}_{2}, 0.2 \mathrm{M} \mathrm{NaCl}$, and $0.25 \%$ Brij-35, and incubated in the same buffer at $37^{\circ} \mathrm{C}$ overnight. The presence of gelatinase activity was detected by determining zones of lysis after Coomassie Brilliant Blue staining. Gelatinolytic activity was detected as clear bands against aqua blue-stained gelatin background.
Transfection and luciferase assay. The calcium-phosphate precipitation method was used for transfection. Cells were seeded on either flexible or rigid bottom plates at a density of $0.5 \times 10^{5}$ cells/well. $48 \mathrm{~h}$ after seeding, medium was changed to $0.4 \mathrm{ml} / \mathrm{well}$ of Dulbecco minimum essential medium supplemented with $0.4 \%$ FBS, and $40 \mu \mathrm{l}$ of calcium phosphate precipitate containing $1.0 \mu \mathrm{g}$ of the plasmid was added. $4 \mathrm{~h}$ after addition of the precipitates, the medium was aspirated and $10 \%$ glycerol in Hepes buffered saline ( $\mathrm{pH} 7.05)$ was added for $1 \mathrm{~min}$. Cells were washed with HBSS, and incubated for an additional $24 \mathrm{~h}$ in RPMI with $0.4 \%$ FBS. Cells on the flexible plates were subjected to cycles of stretch/relaxation for another $24 \mathrm{~h}$ and cell lysates of each well were harvested. Cell harvest and measurement of luciferase activity were performed using a commercially available kit (Promega Corp.). For the standardization of the transfection efficiency, $0.5 \mu \mathrm{g} /$ well of pRSVcat, which has the SV40 enhancer and early promoter sequences, were cotransfected as a control. CAT activities in the cell lysates were measured according to the methods of Nordeen et al. (35).

Determination of TGF- $\beta$ in conditioned media of mesangial cells exposed to mechanical stretch/relaxation. TGF- $\beta$ in conditioned media (RPMI $+0.4 \%$ FCS) of mesangial cells was determined using the mink lung epithelial cell (MV1 Lu; American Type Culture Collection, Rockville, MD) assay $(36,37)$. Human recombinant TGF- $\beta 1$ (R\&D Systems, Inc.) was used to generate a standard curve. In this assay, MV1 Lu cells were plated at $3.5 \times 10^{4}$ cells/well on 24-well plates in RPMI 1640 supplemented with $10 \%$ FCS and cultured for $48 \mathrm{~h}$. The media was then changed to "mesangial cell-conditioned media," consisting of $100 \mu \mathrm{l}$ of conditioned media for mesangial cells exposed

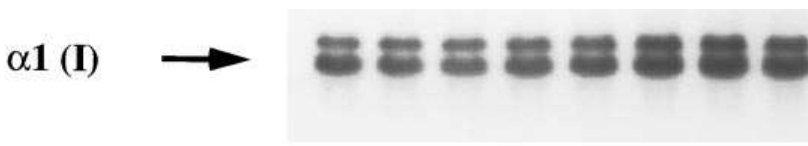

GAPDH
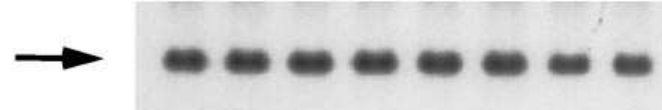

$\alpha 1($ III $) \rightarrow$

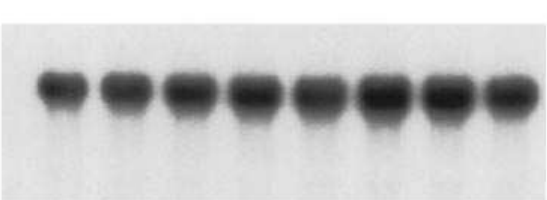

GAPDH
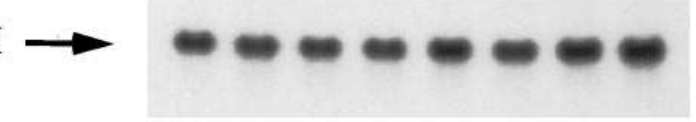

$\alpha \mathbf{1}(\mathrm{IV}) \rightarrow$

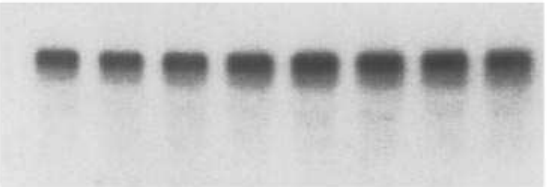

GAPDH
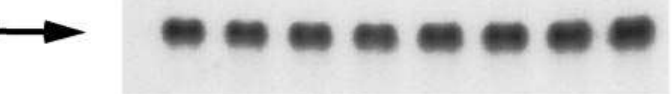

\section{$\begin{array}{lllllllll}\text { Time (h) } & \text { Cont } & 0.5 & 1 & 3 & 6 & 12 & 24 & 48\end{array}$}

Figure 2. Northern blot analysis of RNA extracted from the cells subjected to stretch/relaxation using cDNA probe for $\alpha 1(\mathrm{I}), \alpha 1(\mathrm{III})$, and $\alpha 1$ (IV) collagens. Membranes were stripped and reprobed with GAPDH cDNA. 

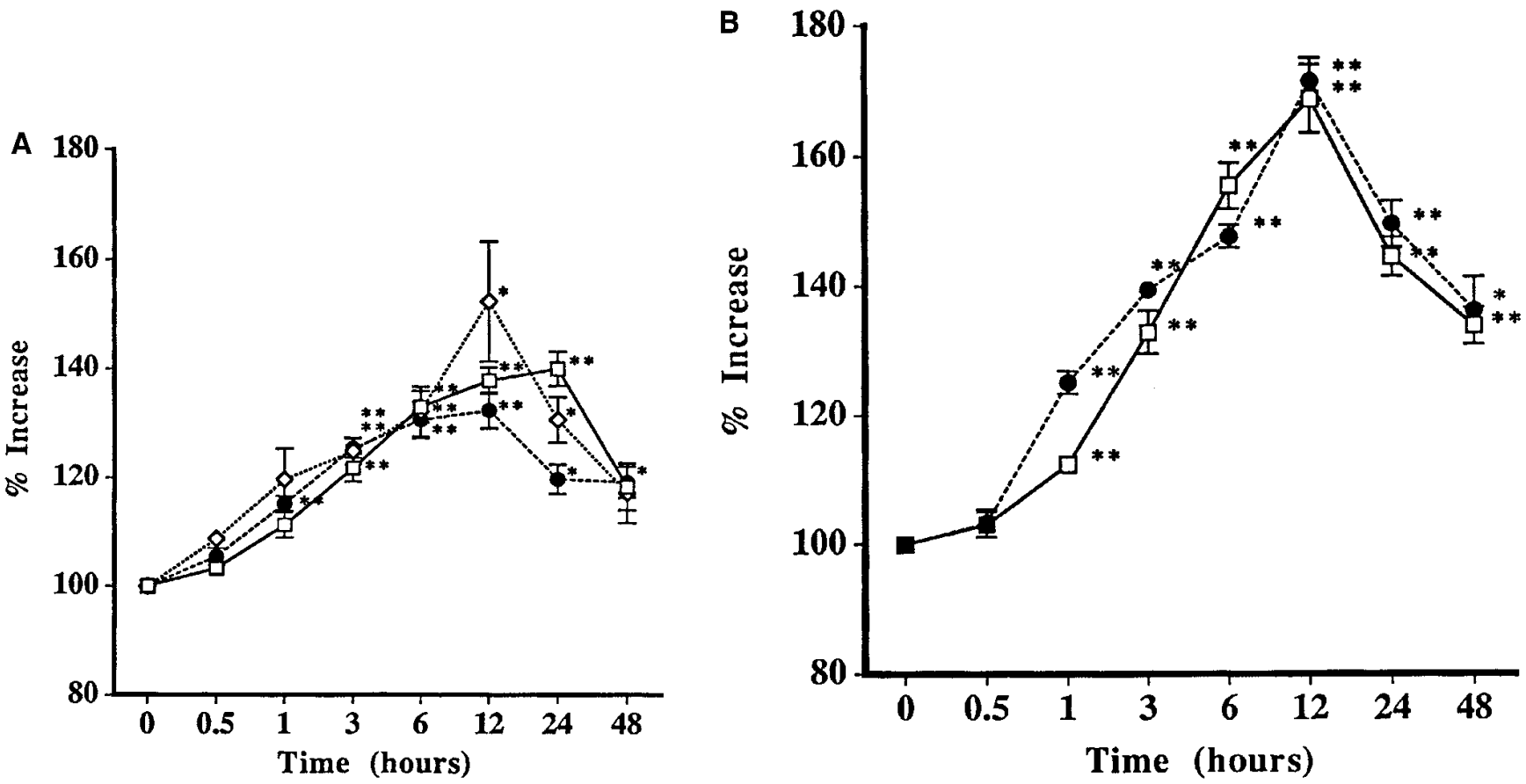

Figure 3. (A) Densitometric analysis of $\alpha 1(\mathrm{I})$ collagen $(\square), \alpha 1(\mathrm{III})$ collagen $(\diamond)$, and $\alpha 1(\mathrm{IV})(\bullet)(n=6)$. (B) Densitometric analysis of fibronectin $(\bullet)$ and laminin $(\square)(n=6)$.

to $3,6,12$, or $24 \mathrm{~h}$ of mechanical stretching or equivalent timed controls $+150 \mu \mathrm{l}$ of fresh RPMI $+10 \%$ FCS. For some samples, conditioned media was also treated with $10 \mathrm{~N} \mathrm{HCl}$ to achieve a $\mathrm{pH}<2.0$ for $30 \mathrm{~min}$, followed by neutralization with $\mathrm{NaOH}$ to convert latent TGF- $\beta$ to its active form. A subset of samples were preincubated for $30 \mathrm{~min}$ at room temperature with a polyclonal rabbit anti-TGF- $\beta 1$ antibody $(30 \mu \mathrm{g} / \mathrm{ml})$ before addition to the cells.

The MV1 Lu cells were incubated for $22 \mathrm{~h}, 1 \mu \mathrm{Ci} /$ well $\left[{ }^{3} \mathrm{H}\right]$ thymidine was added and the cells were incubated for an additional $2 \mathrm{~h}$ before washing with ice cold PBS $\times 2$ and incubating with ice-cold $10 \%$ TCA for $30 \mathrm{~min} \times 2$. The cells were then dissolved in $60 \mu \mathrm{l}$ of $0.5 \%$ SDS, $0.2 \mathrm{~N} \mathrm{NaOH}$ and radioactivity was determined in a scintillation counter.

Statistical analysis. All values are presented as mean \pm SEM, and unpaired Student's $t$ test was used for statistical analysis. Differences were considered significant when $P<0.05$.

\section{Results}

Change in extracellular matrix components. Quiescent mesangial cells were exposed to stretch/relaxation for $48 \mathrm{~h}$ and components of extracellular matrix were detected by immunostaining using fluorescence-labeled antibodies against types I, III, and IV collagen. Immunofluorescence of types I, III, and IV collagen was increased after $48 \mathrm{~h}$ of stretch/relaxation compared with the control cells incubated without stretch/relaxation (Fig. $1 a$ ). The intensity of immunostaining of fibronectin and laminin was also increased by stretch relaxation compared with control (Fig. $1 b$ ). As we have previously reported, subjecting mesangial cells to continuous stretch/relaxation causes alterations in cell morphology from the normal stellate pattern to a straplike appearance, and the cells align themselves with their long axis perpendicular to the direction of stress. As can be seen in Fig. 1, both morphological changes and immunoflu- orescent intensity were more prominent in the cells at the periphery compared with the cells in the center or midperipheral portion of the culture well.

Using cDNA probes, we measured the steady state mRNA levels of types I, III, and IV collagens, laminin, and fibronectin. Figs. 2 and 3 show the results of Northern blot analyses of total RNA isolated from mesangial cells subjected to stretch/relaxation for the indicated times. Exposure of mesangial cells to cycles of stretch/relaxation caused time-dependent increases in mRNA levels of all of these matrix components. The $\alpha 1$ (IV) collagen mRNA level increased within $1 \mathrm{~h}$ after initiating stretch/relaxation and reached maximal levels within $12 \mathrm{~h}$ $(132 \pm 3.4 \%$ of control at $12 \mathrm{~h}, n=6, P<0.05)$. The $\alpha 1$ (I) and $\alpha 1$ (III) collagen mRNA levels also reached maximal levels within $12 \mathrm{~h}(140 \pm 3.1 \%$ of control at $12 \mathrm{~h}, n=6, P<0.05$ and $152 \pm 5.0 \%$ of control at $12 \mathrm{~h}, n=6, P<0.05$, respectively). Fibronectin and laminin mRNA levels reached maximal levels within $6-12 \mathrm{~h}(171 \pm 3.5 \%$ of control at $12 \mathrm{~h}, n=6, P<0.05$ and $169 \pm 5.2 \%$ of control at $12 \mathrm{~h}, n=6, P<0.05$, respectively). Expression of the 1.4-kb mRNA for the housekeeping gene, GAPDH, was unaffected during the course of these experiments.

To determine whether the stretch/relaxation-induced increases in type I collagen mRNA expression involved stimulation of promoter activity, mesangial cells were transfected with constructs of varying lengths of the $5^{\prime}$ untranslated region of the murine $\alpha 1(\mathrm{I})$ collagen gene linked to a luciferase reporter gene. Fig. 4 shows the relative increase in luciferase activities induced by $24 \mathrm{~h}$ of stretch/relaxation in mesangial cells transfected with pGL 0.22, pGL 0.9, and pGL 2.4, and normalized to CAT activity. The luciferase activities in cells subjected to stretch/relaxation were significantly increased compared with the cells without stretch/relaxation $(336.3 \pm 11.5 \%$ for $\mathrm{pGL}$ 


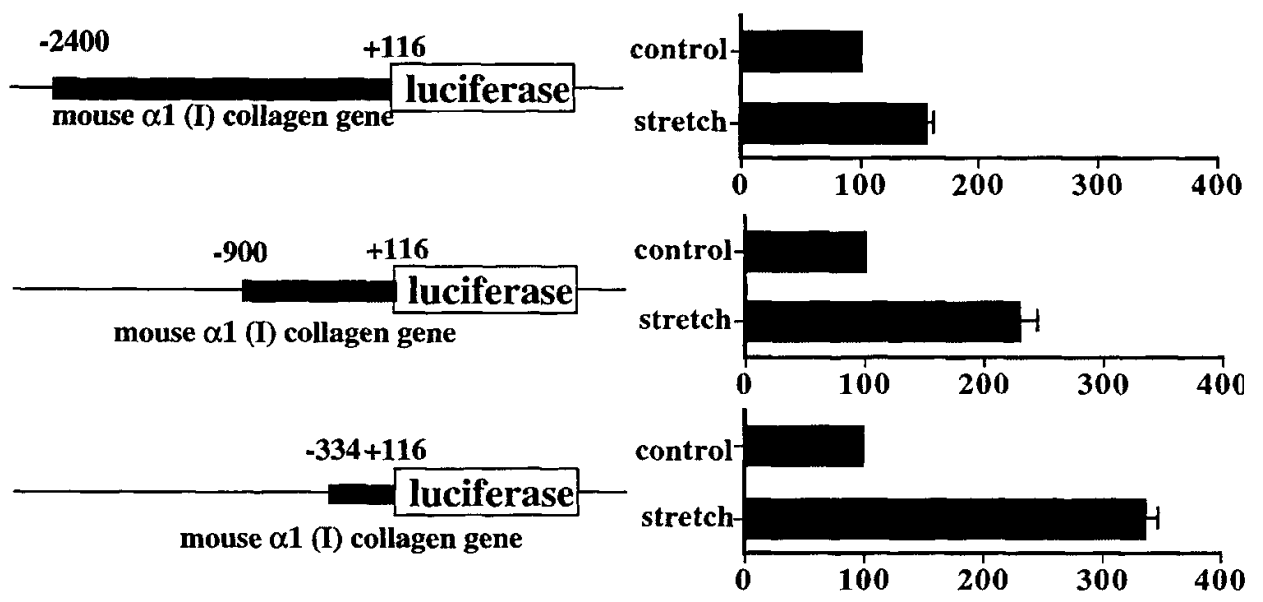

Figure 4. Relative luciferase activity in transfected cells with pGL 2.4, pGL 0.9 , or pGL 0.22 after $24 \mathrm{~h}$ stretch/relaxation compared with the cells without stretching $(n=3)$.
$0.22,229.3 \pm 15.8 \%$ for pGL 0.9 , and $155.2 \pm 6.8 \%$ for pGL 2.4, $P<0.01$ for all constructs, $n=3$ in triplicate samples in each experiment).

Change in gelatinolytic activity. Gelatinolytic activities were observed in the conditioned media of quiescent cells. In rat mesangial cells, the major gelatinolytic activity at $68 \mathrm{kD}$ is produced by the $72 \mathrm{kD} \mathrm{MMP-2}(38,39)$, and in our experiments, a major zone of gelatinolytic activity was observed at $68 \mathrm{kD}$ (Fig. 5). This $68-\mathrm{kD}$ gelatinolytic activity in conditioned media from the control cells increased progressively with time. In the conditioned media from cells subjected to continuous cycles of stretch/relaxation, gelatinolytic activity was decreased compared with the control at corresponding time points from 6 through $48 \mathrm{~h}$. However, at $72 \mathrm{~h}$ the conditioned media of the stretch/relaxation group demonstrated greater activity than control.

A specific cDNA probe to the MMP-2 detected a transcript of $3.1 \mathrm{~kb}$, a size appropriate to MMP-2. The mRNA level of MMP-2 decreased significantly at $6 \mathrm{~h}(78 \pm 3.4 \%$ of control at 6 h, $n=6, P<0.05)$ and then increased after $24 \mathrm{~h}$ of stretch/relaxation $(131 \pm 4.9 \%$ of control at $48 \mathrm{~h}, n=6, P<0.05)$ (Fig. 6). Two mRNA species, 1.0 and $3.5 \mathrm{~kb}$ in size, were recognized by TIMP-2 cDNA. Expression of the $3.5-\mathrm{kb}$ band increased in a time-dependent manner in response to stretch/relaxation, with maximal increases seen at $48 \mathrm{~h}$. The level of expression of the $1.0-\mathrm{kb}$ band was not altered by stretch/relaxation. No expression of TIMP-1 could be noted in cultured mesangial cells.

Changes in TGF- $\beta 1$. Since TGF- $\beta$ has been shown to exert potent effects on regulation of extracellular matrix, we also examined expression of immunoreactive TGF- $\beta 1$. Immunostaining of TGF- $\beta$ indicated no detectable changes in the staining pattern between control and 12-h stretch/relaxation, but a significant increase in staining was observed after $48 \mathrm{~h}$ of stretch/relaxation (Fig. 7), with the greatest staining present at the periphery. The observed timing of increases in mRNA levels of TGF- $\beta 1$ occurred after the initial increases in mRNA levels of matrix component genes (Fig. 8). There was no significant change in TGF- $\beta 1 \mathrm{mRNA}$ levels by $12 \mathrm{~h}$ of stretch/relaxation; however, significant increases were observed by $24 \mathrm{~h}$, with maximal increases seen at $48 \mathrm{~h}(148 \pm 7.8 \%$ of control, $n=$ 5, $P<0.05)$

To determine whether active TGF- $\beta$ was released as an early event in response to mechanical stretching, TGF- $\beta$ activity in conditioned media from control cells or cells exposed to stretch/relaxation for 3,6 , or $12 \mathrm{~h}$ was assayed using the mink lung epithelial cell bioassay (see Methods). In this assay, rhTGF- $\beta 1$ produced a concentration-dependent decrease in $\left[{ }^{3} \mathrm{H}\right]$ thymidine incorporation, which was reversed by addition of neutralizing anti-TGF- $\beta 1$ antibody (percent inhibition of $\left[{ }^{3} \mathrm{H}\right]$ thymidine incorporation with [TGF- $\left.\beta 1\right]$ vs [TGF- $\left.\beta 1\right]+30$ $\mu \mathrm{g} / \mathrm{ml}$ antibody: [500 pg/ml], $70 \mathrm{vs} 8 \%$ inhibition; [ $1 \mathrm{ng} / \mathrm{ml}$ ], 90 vs $40 \%$ inhibition). Therefore, if significantly more active TGF- $\beta 1$ were released early in response to stretch/relaxation, conditioned media from those cells would be expected to inhibit $\left[{ }^{3} \mathrm{H}\right]$ thymidine incorporation compared with conditioned media from nonstretched cells, and this inhibition would be reversible by the neutralizing anti-TGF- $\beta 1$ antibody. However, no significant differences in $\left[{ }^{3} \mathrm{H}\right]$ thymidine incorporation were noted in cells incubated in conditioned media from cells subjected to a varying period of stretch/relaxation compared with conditioned media from their timed controls (percent control: $3 \mathrm{~h}$ stretch/relaxation, $167 \pm 52 \% ; 6 \mathrm{~h}$ stretch/relaxation,

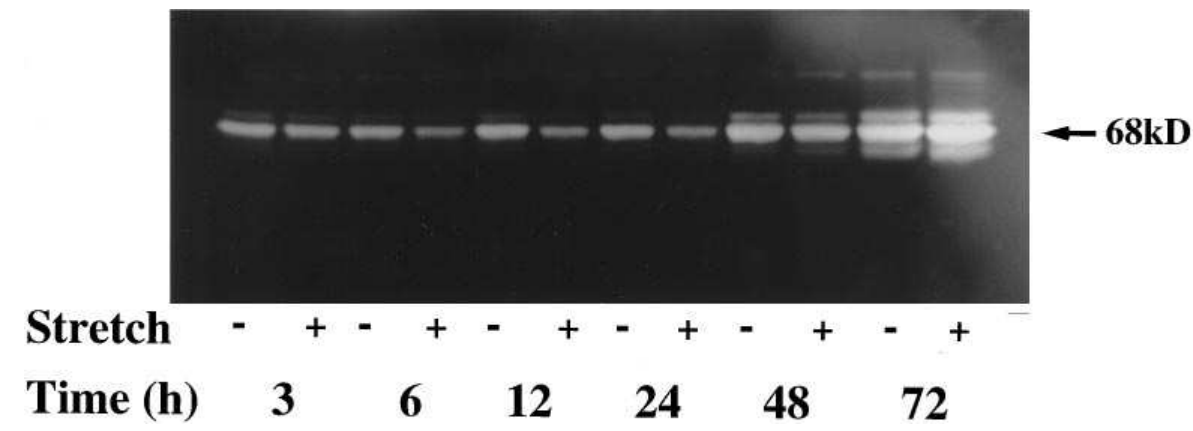

1996
Figure 5. Gelatin zymography of the conditioned medium from the cells with or without stretch/relaxation for indicated time. 


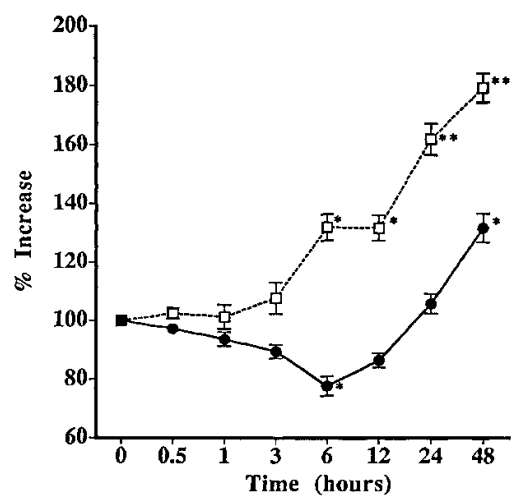

Figure 6. Densitometric analysis of RNA extracted from the cells subjected to stretch/relaxation using cDNA probe for MMP-2 $(\bullet)$ and TIMP-2 ( $\square)$ and normalized to GAPDH expression $(n=6)$.

$142 \pm 42 \% ; 12 \mathrm{~h}$ stretch/relaxation, $166 \pm 44 \% ; n=5$, NS for all time points). In two experiments, conditioned media were also treated with $\mathrm{HCl}$ to convert any latent TGF- $\beta$ to its active form (see Methods), but no consistent differences between conditioned media from control and stretched cells were noted. Although there was a trend for neutralizing antiTGF- $\beta 1$ antibody to increase $\left[{ }^{3} \mathrm{H}\right]$ thymidine incorporation, there were no significant differences between control and stretched mesangial cells (percent nonantibody treatment, control vs stretch/relaxation: 3 h, $223 \pm 61$ vs $160 \pm 40 \%$; 6 h, $217 \pm 59$ vs $133 \pm 41 \%$; 12 h, $220 \pm 46$ vs $126 \pm 40 \%, n=5$, NS).

As a further determination of the potential role of TGF- $\beta$ in the mediation of the early increases in extracellular matrix production by mesangial cells in response to stretch/relaxation, mesangial cells were incubated with the neutralizing antiTGF- $\beta 1$ antibody $(30 \mu \mathrm{g} / \mathrm{ml})$ and subjected to mechanical stretching for $12 \mathrm{~h}$. Compared with control cells, steady state $\alpha 1$ (I) collagen mRNA levels, normalized to GAPDH expression was $170 \pm 20 \%$ of control $(n=5, P<0.05)$. Simultaneous incubation with anti-TGF- $\beta 1$ antibody did not significantly decrease the increased steady state mRNA levels in response to stretch/relaxation $(125 \pm 20 \%$ of non-antibody treated, NS).

\section{Discussion}

In the present studies, we examined the effects of repeated cycles of stretch/relaxation of mesangial cells upon the expression of the genes for extracellular matrix components. Stretch/ relaxation-induced time-dependent increases in steady state mRNA levels of types I, III, and IV collagens, fibronectin, and laminin. Floege et al. (2) have shown in 5/6 nephrectomized rats that the progressive accumulation of mesangial matrix is accompanied by only a $20-50 \%$ increase in expression of matrix components mRNA. Therefore, although the relative increases of mRNA levels in the present study were small, it appears likely that these increases induced by stretch/relaxation reflected overproduction of these matrix components in mesangial cells.

These results established that mechanical stretch/relaxation increased the steady state transcript levels of extracellular matrix genes. Such modulation of gene expression may be achieved either by transcriptional activation or posttranscriptional stabilization of the mRNA. Further insight into alterations of extracellular matrix gene expression was obtained by transient transfection studies with the $\alpha 1$ (I) collagen promoter linked to a luciferase reporter gene. We prepared three constructs with different lengths of $5^{\prime}$ flanking region of $\alpha 1$ (I) collagen. $24 \mathrm{~h}$ of stretch/relaxation induced significant increases in promoter activity, indicating that increases in mRNA levels of $\alpha 1$ (I) collagen by stretch/relaxation were due at least in part to transcriptional activation. Since the increase in luciferase activity was most pronounced in the cells transfected with plasmid containing -222 to +116 of $\alpha 1(\mathrm{I})$ collagen promoter, this region most likely contains the positive response elements required for transcriptional activation in mesangial cells. This finding is consistent with results of transient transfection studies in NIH-3T3 fibroblasts, which revealed only negative regulatory elements upstream from $-222 \mathrm{bp}$ in the mouse $\alpha 1(\mathrm{I})$ promoter (31). However, it is known that collagen type $\alpha 1(\mathrm{I})$ also has transcriptional regulatory sites in the first intron $(40$
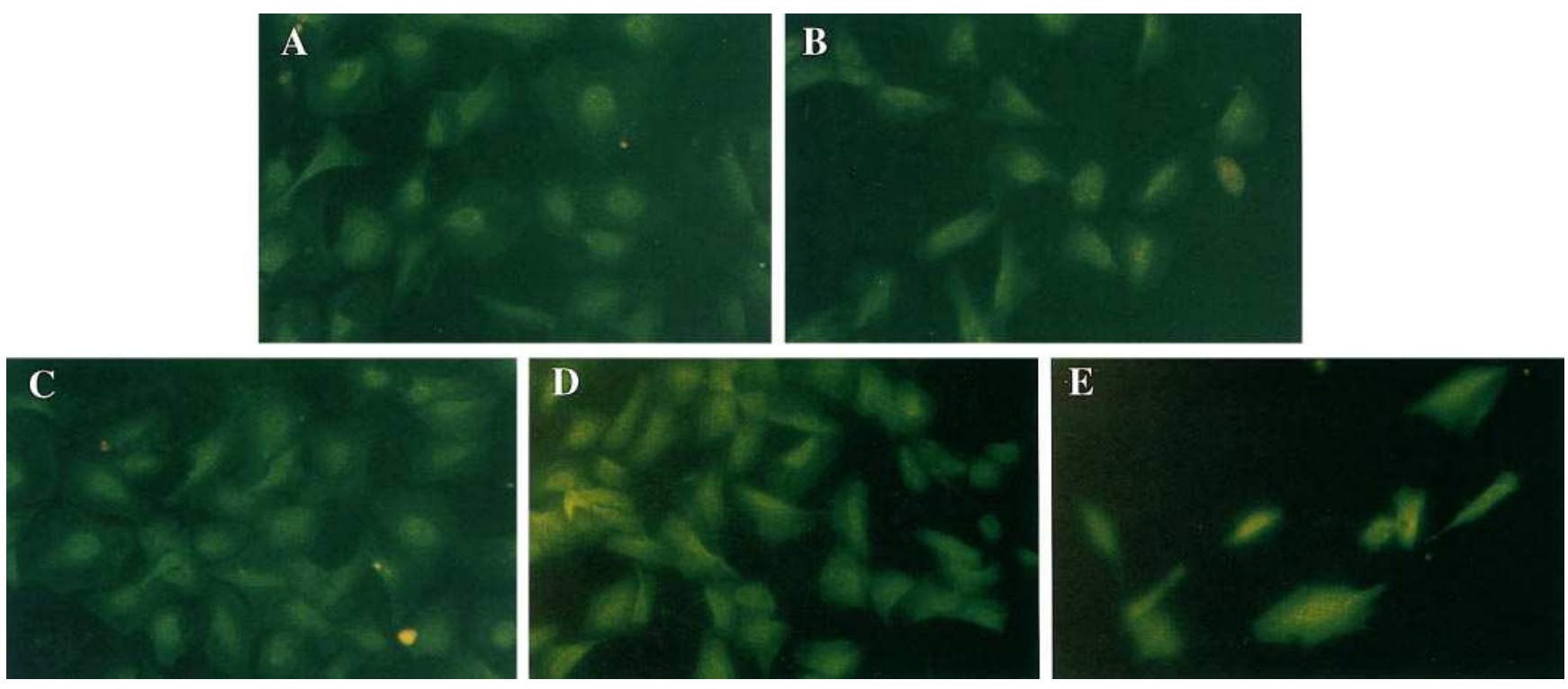

Figure 7. Immunofluorescence of TGF- $\beta 1$. ( $A$ and $C$ ) Cells without stretch/relaxation for $12(A)$ or $48 \mathrm{~h}(C)$. $(B)$ Cells in peripheral portion of the well after $12 \mathrm{~h}$ of stretch relaxation. ( $D$ and $E$ ) Cells after $48 \mathrm{~h}$ of stretch/relaxation in midperipheral portion $(D)$ and in peripheral portion $(E)$. 


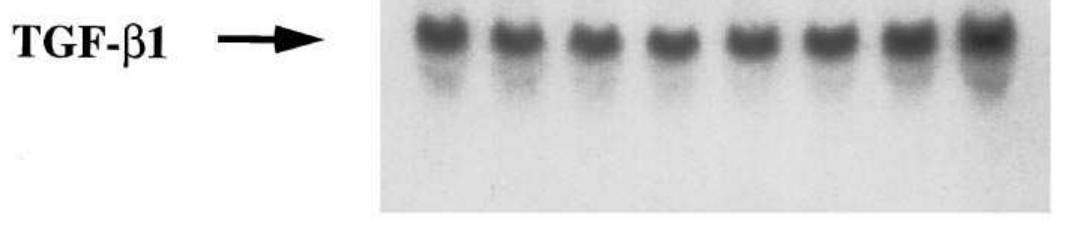

GAPDH
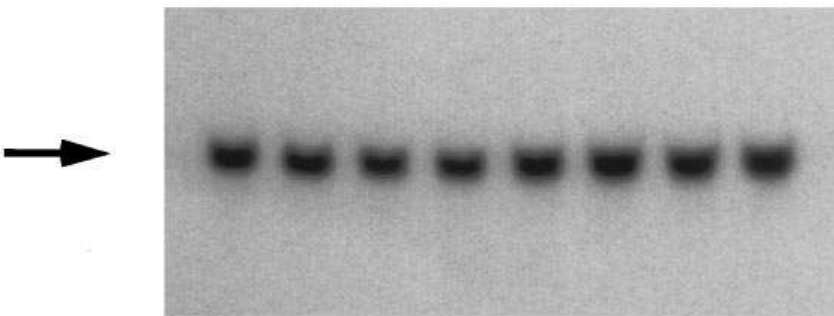

Time (h) $\quad \begin{array}{llllllll}\text { Cont } & 0.5 & 1 & 3 & 6 & 12 & 24 & 48\end{array}$

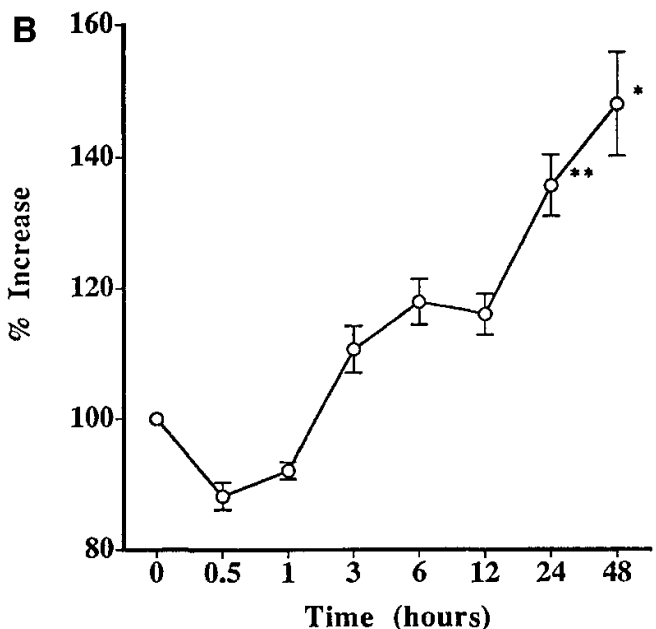

Figure 8. (A) Northern blot analysis of RNA extracted from the cells subjected to stretch/relaxation using cDNA probe for TGF- $\beta 1$. Membranes were stripped and reprobed with GAPDH. $(B)$ Densitometric analysis of TGF- $\beta 1(n=5)$.

42) and tissue-specific regulators at a far upstream $5^{\prime}$ flanking region and in the $3^{\prime}$ flanking region $(43,44)$. Therefore, it is possible that other regulatory sites mediating gene transcription in response to stretch/relaxation also exist.

Immunofluorescent staining of extracellular matrix proteins also increased concomitantly with gene expression after stretch/relaxation. As we previously described (20), cell morphology was changed from a normal stellate pattern to a straplike appearance at the periphery. Intensity of staining and morphological changes were more prominent in cells at the periphery compared with the cells in the center or midperipheral portion of the culture well. Since stretching of the cells was greater at the periphery, these results indicate that greater mechanical deformation caused greater production of matrix components.

Gelatinolytic activity in the conditioned medium of mesangial cells induced by stretch/relaxation showed biphasic changes compared with that of control. This was accompanied by concomitant changes in MMP-2 mRNA. In the first $24 \mathrm{~h}$ after initiation of stretch/relaxation, both gelatinolytic activities and MMP-2 mRNA levels were significantly decreased. In contrast, stretch/relaxation increased TIMP-2 expression in mesangial cells, as shown by analysis of TIMP-2 mRNA. Since activity of MMP-2 is dependent on both the MMP-2 level and the TIMP-2 level, the net effect of initiation of stretch/relaxation was an initial decrease in matrix-degrading activity. Thus, in mesangial cells, stretch/relaxation induced increases in production of matrix components and decreases in matrixdegrading activity in the first $24 \mathrm{~h}$. After more prolonged periods of stretch/relaxation, increases in both MMP-2 mRNA levels and gelatinolytic activity were noted.

There was a significant increase in TGF- $\beta 1$ mRNA levels in mesangial cells after $24 \mathrm{~h}$ of stretch/relaxation, accompanied by increased immunostaining for TGF- $\beta$ at $48 \mathrm{~h}$. TGF- $\beta 1$ has been recognized to exert a wide variety of effects on extracellular matrix production in cultured cells and tissue. Generally,
TGF- $\beta$ induces a net accumulation of extracellular matrix. However, in the present studies it would appear unlikely that all of the increases in matrix component genes by stretch/relaxation were secondary to increased production of TGF- $\beta 1$. TGF- $\beta$ has previously been shown to increase MMP- 2 gene expression and synthesis of MMP-2 in mesangial cells (45-47), and the initial decrease in MMP-2 mRNA expression in response to stretch/relaxation would not be consistent with a TGF- $\beta$-mediated event, although the later increases in mRNA level of MMP-2 after $48 \mathrm{~h}$ of stretch/relaxation may be the result of the increased TGF- $\beta 1$. In addition, although TGF- $\beta$ increases both the mRNA levels and the synthesis of TIMP-1 $(45,48)$, Kawanishi et al. (49) failed to detect a significant stimulatory effect of TGF- $\beta 1$ on TIMP- 2 mRNA expression in mesangial cells. Therefore, it is possible that the initial increases in TIMP-2 mRNA levels were also TGF- $\beta$ independent.

In the mink lung epithelial cell assay, we were not able to detect differences in TGF- $\beta$ activity in conditioned media between control cells and cells subjected to 3,6 , or $12 \mathrm{~h}$ of stretch/relaxation. Furthermore, an anti-TGF- $\beta 1$ neutralizing antibody failed to block the early ( $12 \mathrm{~h})$ increases in steady state $\alpha 1$ (I) collagen mRNA levels. These results do not provide evidence for a crucial role for the early $(<12 \mathrm{~h})$ alterations in the extracellular matrix in response to stretch/relaxation, although it remains possible that the large standard errors observed would preclude determination of statistically significant differences. Our findings also do not completely rule out the possibility that there is local release and autocrine/ paracrine actions of TGF- $\beta$ in response to stretch/relaxation, or that other TGF- $\beta$ species (TGF- $\beta 2$ or 3 ) are involved.

Recent in vivo studies in the rat remnant kidney have also indicated that initial alterations in matrix accumulation may precede increases in local TGF- $\beta$ expression (50). In the $5 / 6$ nephrectomy model, significant increases in type IV collagen mRNA were detected $14 \mathrm{~d}$ after renal ablation in glomerular endothelial, mesangial, and epithelial cells. In contrast, signifi- 
cant increases in TGF- $\beta 1$ mRNA expression were not noted until day 24 and were initially localized to endothelial cells and mesangial cells of capillary loops at the vascular pole that demonstrated the greatest dilatation (50). In these studies, increased angiotensinogen mRNA expression colocalized with TGF- $\beta$ mRNA expression, and Kagami et al. (37) demonstrated that angiotensin II induced glomerular TGF- $\beta$ expression, indicating that increased local glomerular production of angiotensin II may mediate TGF- $\beta$ production and progression of the sclerotic lesion. In this regard, we have recently found that in cultured mesangial cells, mechanical deformation induced angiotensinogen activity and increased type 1 angiotensin II receptor levels (Becker, B.N., T. Yasuda, S. Kondo, S. Vishnaith, T. Homma, and R.C. Harris. Manuscript submitted for publication).

In conclusion, mechanical stress led to matrix accumulation in cultured mesangial cells by increasing synthesis and decreasing degradation of matrix components. These alterations may be mediated by both induction and suppression of gene expression of specific components of the matrix regulatory system. The observed induction of TGF- $\beta 1$ suggests it plays an important role in matrix accumulation occurring in response to continued stretch/relaxation, but does not initiate the initial alterations in extracellular matrix in response to mechanical stress. We conclude that increased gene and protein expression of extracellular matrix by mesangial cells in response to altered mechanical forces may contribute to the development of sclerosis.

\section{Acknowledgments}

This work was supported by funds from the Department of Veterans Affairs and by National Institutes of Health grant DK-39261. R.C. Harris is a Clinical Investigator in the Career Development Program of the Veterans Administration.

\section{References}

1. Adler, S., L.J. Striker, G.E. Striker, D.T. Perkinson, J. Hibbert, and W.G. Couser. 1986. Studies of progressive glomerular sclerosis in the rat. Am. J. Pathol. 123:553-562.

2. Floege, J., C.E. Alpers, M.W. Burns, P. Pritzl, K. Gordon, W.G. Couser, and R.J. Johnson. 1992. Glomerular cells, extracellular matrix accumulation, and the development of glomerulosclerosis in the remnant kidney model. Lab. Invest. 66:485-497.

3. Striker, L.M., P.D. Killen, E. Chi, and G.E. Striker. 1984. The composition of glomerulosclerosis. Studies in focal sclerosis, crescentic glomerulonephritis, and membranoproliferative glomerulonephritis. Lab. Invest. 51:181192.

4. Matrisian, L.M. 1990. Metalloproteinases and their inhibitors in matrix remodeling. Trends Genet. 6:121-125.

5. Woessner, J.F., Jr. 1991. Matrix metalloproteinases and their inhibitors in connective tissue remolding. FASEB J. 5:2145-2154.

6. Klahr, S., G. Schreiner, and I. Ichikawa. 1988. The progression of renal disease. N. Engl. J. Med. 318:1657-1664.

7. Border, W.A., S. Okuda, L.R. Languino, and E. Ruoslahti. 1990. Transforming growth factor- $\beta$ regulates production of proteoglycans by mesangial cells. Kidney Int. 37:689-695.

8. Mene, P., M.S. Simonson, and M.J. Dunn. 1989. Physiology of the mesangial cell. Physiol. Rev. 69:1347-1424.

9. MacKay, K., L.J. Striker, J.W. Stauffer, T. Doi, L.Y. Agodoa, and G.E. Striker. 1989. Transforming growth factor- $\beta$ : murine glomerular receptors and responses of isolated glomerular cells. J. Clin. Invest. 83:1160-1167.

10. Okuda, S., L.R. Languino, E. Ruoslahti, and W.A. Border. 1990. Elevated expression of transforming growth factor- $\beta$ and proteoglycan production in experimental glomerulonephritis. Possible role in expansion of the mesangial extracellular matrix. J. Clin. Invest. 86:453-462.

11. Border, W.A., S. Okuda, L.R. Languino, M.B. Sporn, and E. Ruoslahti. 1990. Suppression of experimental glomerulonephritis by antiserum against transforming growth factor $\beta 1$. Nature (Lond.). 346:371-374.
12. Border, W.A., N.A. Noble, T. Yamamoto, J.R. Harper, Y. Yamaguchi, M.D. Pierschbacher, and E. Rouslahti. 1992. Natural inhibitor of transforming growth factor- $\beta$ protects against scarring in experimental kidney disease. $\mathrm{Na}$ ture (Lond.). 360:361-364

13. Isaka, Y., Y. Fujiwara, N. Ueda, Y. Kaneda, T. Kamada, and E. Imai. 1993. Glomerulosclerosis induced by in vivo transfection of transforming growth factor- $\beta$ or platelet-derived growth factor gene into the rat kidney. $J$. Clin. Invest. 92:2597-2601.

14. Barnard, J.A., R.M. Lyons, and H.L. Moses. 1990. The cell biology of transforming growth factor $\beta$. Biochim. Biophys. Acta. 1032:17-87.

15. Brenner, B.M. 1985. Nephron adaptation to renal injury or ablation. Am. J. Physiol. 249:324-337.

16. Sakai, T., and W. Kriz. 1987. The structural relationship between mesangial cells and basement membrane of the renal glomerulus. Anat. Embryol. 176:373-386.

17. Morgan, H.E., E.E. Gordon, Y. Kira, B.H.L. Chua, L.A. Russo, C.J. Peterson, P.J. McDermotte, and P.A. Watson. 1987. Biochemical mechanisms of cardiac hypertrophy. Annu. Rev. Physiol. 49:533-543.

18. Owens, G.K. 1989. Control of hypertrophic versus hyperplastic growth of vascular smooth muscle cells. Am. J. Physiol. 257:1755-1765.

19. Akai, Y., T. Homma, K.D. Burns, T. Yasuda, K.F. Badr, and R.C. Harris. 1994. Mechanical stretch/relaxation of cultured rat mesangial cells induces protooncogenes and cyclooxygenase. Am. J. Physiol. 267:482-490.

20. Harris, R.C., M.A. Haralson, and K.F. Badr. 1992. Continuous stretchrelaxation in culture alters rat mesangial cell morphology, growth characteristics and metabolic activity. Lab. Invest. 66:548-554

21. Homma, T., Y. Akai, K.D. Burns, and R.C. Harris. 1992. Activation of S6 kinase by repeated cycles of stretching and relaxation in rat glomerular mesangial cells: evidence for involvement of protein kinase C. J. Biol. Chem. 267: 23129-23135.

22. Riser, B.L., P. Cortes, X. Zhao, J. Bernstein, F. Dumler, and R.G. Narins. 1992. Intraglomerular pressure and mesangial stretching stimulate matrix formation in the rat. J. Clin. Invest. 90:1932-1943.

23. Genovese, C., D. Rowe, and B. Kream. 1984. Construction of DNA sequences complementary to rat $\alpha 1$ and $\alpha 2$ collagen mRNA and their use in studying the regulation of type I collagen synthesis by 1,25 -dihydroxyvitamin $\mathrm{D}$. Biochemistry. 23:6210-6216.

24. Glumoff, V., J.K. Makela, and E. Vuorio. 1994. Cloning of cDNA for rat proo1(III) collagen mRNA. Different expression patterns of type I and type III collagen and fibronectin genes in experimental granulation tissue. Biochim. Biophys. Acta. 1217:41-48.

25. Wood, L., N. Theriault, and G. Vogeli. 1988. cDNA clones completing the nucleotide and derived amino acid sequence of the alpha 1 chain of basement membrane (type IV) collagen from mouse. FEBS Lett. 227:5-8.

26. Schwarzbauer, J.E., J.W. Tamkun, I.R. Lemischka, and R.O. Hynes. 1983. Three different fibronectin mRNAs arise by alternative splicing within the coding region. Cell. 35:421-431.

27. Pikkarainen, T., R. Eddy, Y. Fukushima, M. Byers, T. Shows, T. Pihlajaniemi, M. Saraste, and K. Tryggvason. 1987. Human laminin B1 chain. A multidomain protein with gene (LAMB1) locus in the $\mathrm{q} 22$ region of chromosome 7 . J. Biol. Chem. 262:10454-10462.

28. Huhtala, P., R.L. Eddy, Y.S. Fan, M.G. Byers, T.B. Shows, and K. Tryggvason. 1990. Completion of the primary structure of the human type IV collagenase preproenzyme and assignment of the gene to the q21 region of chromosome 16. Genomics. 6:554-559.

29. Willard, H.F., S.J. Durfy, M.M. Mahtani, H. Dorkins, K.E. Davies, and B.R. Williams. 1989. Regional localization of the TIMP gene on the human X chromosome. Extension of a conserved synteny and likage group on proximal Xp. Hum. Genet. 81:234-238.

30. Kasid, A., G.I. Bell, and E.P. Director. 1988. Effects of transforming growth factor- $\beta$ on human lymphokine-activated killer cell precursors. Autocrine inhibition of cellular proliferation and differentiation to immune killer cells. J. Immunol. 141:690-698.

31. Karsenty, G., and B. de Crombrugghe. 1990. Two different negative and one positive regulatory factors interact with a short promoter segment of the $\alpha 1$ (I) collagen gene. J. Biol. Chem. 265:9934-9942.

32. Homma, T., R.L. Hoover, and R.C. Harris. 1990. Loop diuretic-sensitive potassium flux pathways of rat glomerular mesangial cells. Am. J. Physiol. 258:862-870.

33. Chomczynski, P., and N. Sacchi. 1987. Single-step method of RNA isolation by acid guanidinium thiocyanate-phenol-chloroform extraction. Anal. Biochem. 162:156-159.

34. Heussen, C., and E.B. Dowdle. 1980. Electrophoretic analysis of plasminogen activators in polyacrylamide gels containing sodium dodecyl sulfate and copolymerized substrates. Anal. Biochem. 102:196-202.

35. Nordeen, S.K., P.P. Green III, and D.M. Fowlkes. 1987. Laboratory methods. A rapid, sensitive, and inexpensive assay for chloramphenicol acetyltransferase. DNA (NY). 6:173-178.

36. Howe, P.H., M.R. Cunningham, and E.B. Leof. 1990. Inhibition of mink lung epithelial cell proliferation by transforming growth factor- $\beta$ is coupled through a pertussis-toxin-sensitive substrate. Biochem. J. 266:537-543.

37. Kagami, S., W.A. Border, D.E. Miller, and N.A. Noble. 1994. Angio- 
tensin II stimulates extracellular matrix protein synthesis through induction of transforming growth factor- $\beta$ expression in rat glomerular mesangial cells. $J$. Clin. Invest. 93:2431-2437.

38. Davies, M., G.J. Thomas, J. Martin, and D.H. Lovett. 1988. The purification and characterization of a glomerular-basement-membrane-degrading neutral proteinase from rat mesangial cells. Biochem. J. 251:419-425.

39. Marti, H.-P., L. McNeil, M. Davis, J. Martin, and D.H. Lovett. 1993. Homology cloning of rat $72 \mathrm{kDa}$ type IV collagenase: cytokine and second-messenger inducibility in glomerular mesangial cells. Biochem. J. 291:441-446.

40. Bornstein, P., J. McKay, J.K. Morishima, S. Devarayalu, and R.E. Gelinas. 1987. Regulatory elements in the first intron contribute to transcriptional control of the human $\alpha 1(\mathrm{I})$ collagen gene. Proc. Natl. Acad. Sci. USA. 84:88698873 .

41. Bornstein, P., and J. McKay. 1988. The first intron of the $\alpha 1$ (I) collagen gene contains several transcriptional regulatory elements. J. Biol. Chem. 263: 1603-1606.

42. Rossouw, C.M.S., W.P. Vergeer, S.J. du Plooy, M.P. Bernard, F. Ramirez, and W.J. de Wet. 1987. DNA sequences in the first intron of the human pro- $\alpha 1$ (I) collagen gene enhance transcription. J. Biol. Chem. 262:1515115157 .

43. Bedalov, A., D.T. Breault, B.P. Sokolov, A.C. Lichtler, I. Bedalov, S.H. Clark, K. Mack, J.S. Khillan, C.O. Woody, B.E. Kream, et al. 1994. Regulation of the $\alpha 1(\mathrm{I})$ collagen promoter in vascular smooth muscle cells. Comparison with other $\alpha 1(\mathrm{I})$ collagen-producing cells in transgenic animals and cultured cells. J. Biol. Chem. 269:4903-4909.
44. Pavlin, D., A.C. Lichtler, A. Bedalov, B.E. Kream, J.R. Harrison, H.F. Thomas, G.A. Gronowicz, S.H. Clark, C.O. Woody, and D.W. Rowe. 1992. Differential utilization of regulatory domains within the $\alpha 1$ (I) collagen promoter in osseous and fibroblastic cells. J. Cell Biol. 116:227-236.

45. Marti, H.-P., L. McNeil, G. Thomas, M. Davis, and D.H. Lovett. 1992. Molecular characterization of a low molecular weight matrix metalloprtoeinase secreted by glomerular mesangial cells as PUMP-1. Biochem. J. 285:899-905.

46. Marti, H.P., L. Lee, M. Kashgarian, and D.H. Lovett. 1994. Transforming growth factor- $\beta 1$ stimulates glomerular mesangial cell synthesis of the $72-\mathrm{kd}$ type IV collagenase. Am. J. Pathol. 144:82-94.

47. Martin, J., J. Knowlden, M. Davies and J.D. Williams. 1994. Identification and independent regulation of human mesangial cell metalloproteinases. Kidney Int. 46:877-885.

48. Overall, C.M., J.L. Wrana, and J. Sodek. 1989. Independent regulation of collagenase, $72-\mathrm{kDa}$ progelatinase, and metalloendoproteinase inhibitor expression in human fibroblasts by transforming growth factor- $\beta$. J. Biol. Chem. 264:1860-1869.

49. Kawanishi, S., E. Imai, T. Moriyama, M. Takenaka, S. Ochi, Y. Fujiwara, T. Noguchi, T. Tanaka, T. Kamada, and N. Ueda. 1991. Differential regulation of TIMP 1 and 2 and stromelysin gene expression by interleukin 1 and transforming growth factor- $\beta$ in cultured rat mesangial cell. J. Am. Soc. Nephrol. 2:577 (Abstr.)

50. Lee, L.K., T.W. Meyer, A.S. Polock, and D.H. Lovett. 1995. Endothelial cell injury initiates glomerular sclerosis in the rat remnant kidney. J. Clin. Invest. 96:953-964. 